\title{
ILOVNATE ZAPOLNITVE V UDORNICAH V ZALEDJU IZVIROV LJUBLJANICE
}

\author{
Uroš Stepišnik \\ Oddelek za geografijo, Filozofska fakulteta, Aškerčeva 2, SI-I000 Ljubljana \\ e-mail: uros.stepisnik@ff.uni-lj.si
}

Izvirni znanstveni članek

COBISS 1.01

\section{Izvleček}

$\mathrm{V}$ besedilu so obravnavani procesi oblikovanja in preoblikovanja udornic v neposrednem zaledju izvirov Ljubljanice pri Vrhniki. Podrobneje so proučene značilnosti in mehanizmi oblikovanja ilovnatih uravnav $\mathrm{v}$ dneh udornic. Uravnave $\mathrm{v}$ dneh udornic so posledica sedimentacije ilovnatega materiala iz poplavne vode, ki je ob višjih nivojih piezometra zapolnjevala dna udornic. Globina ilovnatih zapolnitev, ki večinoma presega globino 30 metrov, je bila ugotovljena z uporabo metode električne upornosti tal.

Ključne besede: kras, udornice, pobočja, sedimenti, meritve električne upornosti.

\section{LOAMY FILLS IN COLLAPSE DOLINES NEAR LJUBLJANICA SPRINGS}

\begin{abstract}
The article discusses formation and transformation processes of collapse dolines in the hinterland of Ljubljanica river springs near Vrhnika. The characteristics and mechanisms of flat loamy sediment floors in collapse dolines have been studied in detail. Loamy sediment fills in the collapse dolines are the result of suspended material sedimentation from floodwaters that inundated lower parts of collapse dolines. The method of ground electrical resistance established that the thickness of loamy sediment fills might reach more than 30 meters.
\end{abstract}

Key words: karst, collapse dolines, slopes, sediments, electric resistance measurement. 


\section{UVOD}

Udornice so površinske kraške globeli različnih oblik in velikosti, katerih nastanek povezujemo s točkastim vertikalnim odnašanjem kamnine v podzemlje, bodisi z nenadnimi udori nad jamskimi prostori, bodisi s postopnim odnašanjem kamnine nad aktivnimi jamskimi rovi (Stepišnik, 2001). Kljub temu, da jih strokovna krasoslovna literatura opredeljuje kot globeli z očitnim nastankom nad votlino (Cramer, 1941, 327; Gams, 1973, 29; Ford, Williams, 1989, 406), tega pri vseh globelih, ki jim strokovno pripada termin udornice, ni mogoče dokazati.

Večina krasoslovne literature nastanek udornic samoumevno pripisuje udorom jamskega stropovja. To poimenovanje izvira iz opažanja, da so nekatera prepadna pobočja udornic in vhodi $\mathrm{v}$ jamske prostore $\mathrm{v}$ dneh nekaterih udornic nedvomno povezana $\mathrm{z}$ udorom jamske dvorane in da se nekateri jamski rovi končajo s podorom v območju udornic. Prostornine nekaterih največjih udornic močno presegajo prostornine največjih jamskih dvoran, zato mehanizem nastanka večjih udornic ne more biti nenaden udor, ampak postopno spodjedanje materiala nad aktivnimi jamskimi rovi (Habič, 1963).

V slovenski strokovni literaturi naletimo na različne izraze, ki se nanašajo na kraške globeli udornega nastanka. Slovenska kraška terminologija (Gams, 1973) navaja udornico kot pogosto ime za udorno vrtačo, lahko tudi udorno dolino. Uporablja se tudi izraze koleševka ali koliševka, za katero Slovenska kraška terminologija (Gams, 1973) pravi, da je več deset metrov globoka in široka kotanja, običajno s skalnim, prepadnim pobočjem in z vidnim dnom. Po prevladujočem naziranju so koliševke udornega nastanka (Gams, 1973). Habič (1963) je med koliševke štel vse globoke udornice s prepadnimi ali zelo strmimi pobočji, ki se v dneh ne nadaljujejo v podzemne rove. Dna so zasuta s podornim skalovjem, gruščem ali preperelino, ki tvorijo ravno ali lijakasto dno. Ime kukava je v Slovenski kraški literaturi predstavljena kot ljudsko ime za vrtačo (Gams, 1973). Habič (1963) je med kukave štel vse udornice, ki imajo v dnu dostop do podzemnih rovov. Šušteršič (1973) predlaga termin kukava za povečane udornice in konte. Za poimenovanje različnih oblik udornic Šušteršič (1984) predlaga izraze udorno brezno, udornica in globoščak, ki naj bi opredelili različno razvojno stopnjo udornic.

Beseda koliševka izvira iz korena kal, torej iz imena kališevka (Šivic Dular, 2005). Prav tako se na starih kartah redko pojavi beseda kališevka namesto zapisa koliševka. Beseda kukava pa etimološko ni dokončno pojasnjena. Najverjetneje izvira iz praslovanske besede kukava, ki pomeni ‘osamljen, odmaknjen kraj' (Šivic Dular, 2005).

Izraz udornica se je začel uporabljati v slovenski strokovni literaturi v šestdesetih letih kot termin, prirejen splošnemu pojmu centrične globeli, domnevno nastale s podorom stropa nad kraško votlino. Do danes je skoraj v celoti izpodrinil izraza udorna vrtača in udorna dolina, ki sta pomensko enaka, dobesedno pa sta prevoda nemškega termina 'die Einsturzdoline' (Šušteršič, 1984).

V Sloveniji so večje udornice najbolj pogoste na pretočnem krasu, v zaledju večjih kraških ponikalnic, kjer vode vnašajo večje količine netopnega materiala v podzemlje. Večje skupine udornic so v porečju kraške Ljubljanice med Pivško kotlino, Cerkniškim poljem in Ljubljanskim barjem, delih Krasa nad podzemnimi tokovi Reke, v Matarskem podolju, Slavenskem ravniku in zahodni Suhi krajini. 
Namen članka je podrobneje razčleniti procese, ki so oblikovali nekatere udornice v zaledju izvirov Ljubljanice pri Vrhniki. Poseben poudarek je na interpretaciji procesov vnašanja ilovnatega materiala $\mathrm{v}$ dna udornic $\mathrm{z}$ rezultati meritev električne upornosti tal, ki sem ga opravil z geoelektričnim radarjem SuperSting R1/IP.

\section{PROCESI V UDORNICAH}

V krasoslovni literaturi se je uveljavilo več delitev udornic glede na obliko. Najpogostejša je delitev udornic na stare in mlade (Habič, 1963, 128). Oblika udornic je rezultat ravnovesja med različnimi procesi v udornici, ki oblikujejo udornice $\mathrm{v}$ dinamičnem kraškem površju. Za razumevanje oblikovanosti in razvoja udornic je potrebno opredeliti procese $\mathrm{v}$ udornicah. Dinamika, trajanje in obseg delovanja določenih procesov v udornicah vpliva na način razvoja udornic, na njihovo velikost in obliko. Odvisni so predvsem od procesov odnašanja kamnine v podzemlju, od naklonov pobočij in od mehanskih lastnosti kamnine, ki pa znotraj posameznih udornic niso homogene (Stepišnik, 2006). Zato klasične delitve udornic po razvojnih stopnjah, kot jih navaja strokovna literatura, niso primerne.

Nastanek manjših udornic je vezan na udor, po katerem se udornice tudi imenujejo. Nastane s porušitvijo statičnega ravnovesja stropa jamske dvorane, kar ima za posledico udor oziroma porušitev jamskega stropa. V trenutku porušitve nastane kvalitativna sprememba, saj podzemska kraška oblika preide v površinsko kraško obliko. Od udora dalje procesi v udornici niso omejeni le na speleološke procese, ampak začnejo v njej delovati vsi eksogeni geomorfni procesi, ki delujejo tudi na okoliškem površju. Spremeni se tudi formalno poimenovanje oblik, saj jamske stene in dele ohranjenega stropa po udornu imenujemo in obravnavamo kot kraška pobočja.

Postopnemu spodjedanju materiala nad podzemskim tokom pripisujemo nastanek večjih udornic. Od časa trajanja tega procesa je odvisna velikost udornic, od dinamike pa so odvisni geomorfne oblike in nakloni pobočij udornic. V primeru, da je dinamika spodjedanja materiala pod udornico intenzivnejša od mehanskega preperevanja pobočij, se bodo oblikovale stene oziroma strmejša pobočja.

Kamnina s preperevanjem prehaja v transportno obliko. V pobočjih udornic prevladujeta dve vrsti preperevanja: mehansko in kemično. Mehansko povzroča razpad kamnine na manjše kose, ki jih različni pobočni procesi odnašajo proti dnu udornice. Dinamika mehanskega preperevanja matične kamnine vpliva na dinamiko pobočnih procesov. Kemično preperevanje ali korozija je prevladujoč način preperevanja kraškega površja. Dinamika kemičnega preperevanja je v grobem premosorazmerna specifičnemu odtoku padavinske vode (Gams, 2004).

Kopičenje materiala je prisotno v vseh delih udornice, ki se nahajajo pod stenastimi ali strmimi skalnimi pobočji.Akumulirana preperelinaje pod stenami navadno odloženakotmelišče ali kot večji podorni bloki, v drugih delih pobočij preperelino prekriva prst. Dinamika pobočnih procesov v meliščih je odvisna od debeline melišč in od naklona pobočij (Scheidegger, 1974). Akumulirana preperelina, ki jo prekriva prst, je lahko podvržena počasnemu premeščanju mase po pobočju navzdol. 
$\mathrm{V}$ nadaljevanju imenujem pobočja, kjer so stene, melišča ali počasnejši mehanski pobočni procesi, aktivna pobočja. Ta pobočja so vsi deli pobočij udornice, kjer so aktivni pobočni procesi mehanskega premeščanja mase vzporedno s pobočjem navzdol. Območja, kjer ti procesi niso več prisotni in na njih prevladuje odtok kamnine $\mathrm{v}$ raztopini oziroma kemično preperevanje, v nadaljevanju imenujem uravnotežena pobočja, saj se na njih vzpostavi ravnotežje med dinamiko mehanskih pobočnih procesov in dinamiko kemičnega preperevanja (Stepišnik, 2006).

$\mathrm{V}$ dneh udornic je lahko prisotnih več različnih geomorfnih procesov, ki jih različno oblikujejo. V udornicah, ki jih spodjedajo aktivni vodni tokovi v podzemlju, je v dnu navadno lijakasta globel v grušču in podornih blokih. V primeru, da je spodjedanje iz dna odneslo večino prepereline iz pobočij udornice ali pa je piezometrični nivo v bližini površja, se pojavi v dnu udornice vodni tok ali jezero. Če proces spodjedanja ni več prisoten, dno postaja vedno manj lijakasto, blagih oblik in ga zapolni drobnejša preperelina. Na preperelini se lahko odlaga ilovnat material, ki prihaja $\mathrm{v}$ dno udornice iz pobočij, kjer se ilovica pojavlja kot polnilo razpadlih jamskih rovov.

Dna nekaterih udornic so poplavljena oziroma ojezerjena le ob dvigu piezometričnega nivoja. V primeru, da voda s seboj prinaša netopen lebdeč material, se bo le-ta v dnu udornice odlagal iz stoječe vode. Ob vsaki poplavi se bo odložila plast drobnega ilovnatega materiala, podobno kot se dogaja ob poplavah $\mathrm{v}$ jamskih rovih. Tako se $\mathrm{v}$ udornicah odlaga material iz poplavnih vod, ki ustvarja obsežna uravnana ilovnata dna (Stepišnik, 2001).

\section{UDORNICE V ZALEDJU IZVIROV LJUBLJANICE PRI VRHNIKI}

Porečje kraške Ljubljanice je zaledje izvirov Ljubljanice na jugozahodnem delu Ljubljanskega barja, ki sega do južnega dela Pivške kotline in Babnega polja na jugu, Rovtarskega hribovja, dela Hotenjskega podolja in Hrušice na zahodu ter Bloške in Pokojiške planote na vzhodu (Gospodarič, Habič, 1976).

Na območju porečja kraške Ljubljanice se nahaja več sto udornic različnih velikosti in oblik. Večje udornice se nahajajo v zaledju izvirov Ljubljanice pri Vrhniki, na območju med Ljubljanskim barjem ter Logaškim poljem, med Logaškim in Planinskim poljem, na Logaško begunjskem ravniku, med Cerkniškim in Planinskim poljem, med Postojnsko kotlino in Planinskim poljem ter med Cerkniškim in Loškim poljem. Nekaj udornic se nahaja tudi na Pokojiški planoti, ena pa je na južnem pobočju Javornikov.

Na zahodnem obrobju Ljubljanskega barja pri Vrhniki, v bližini zatrepnih dolin Močilnik in Retovje, kjer izvira del kraške Ljubljanice, je skupina sedmih večjih udornic (slika 1).

Območje gradijo debelo plastoviti zgornjejurski apnenci. Vpad skladov je okoli 30 stopinj proti zahodu (Pleničar, 1964). Hidrološko udornice praviloma ležijo na območju koncentriranega podzemnega vodnega toka. Raziskave zalitih jam na območju udornic kažejo, da danes aktivni jamski rovi ne potekajo pod udornicami, ampak v njihovi bližini (Ilič, 2002).

Udornice so si zelo podobne. Pobočja udornic so povečini strma in aktivna. V Meletovi dolini, Nagodetovem dolu in Babnem dolu so deli pobočij stenoviti, pod njimi pa se nahajajo 
melišča. Dna vseh udornic so prekrita z ilovnatim sedimentom in bolj ali manj uravnana. Nadmorska višina dnov je v višinskem razponu 10 metrov med 294 in 304 metri nadmorske višine.

Slika 1: Udornice v zaledju izvirov Ljubljanice

Figure 1: Collapse dolines near Ljubljanica River springs

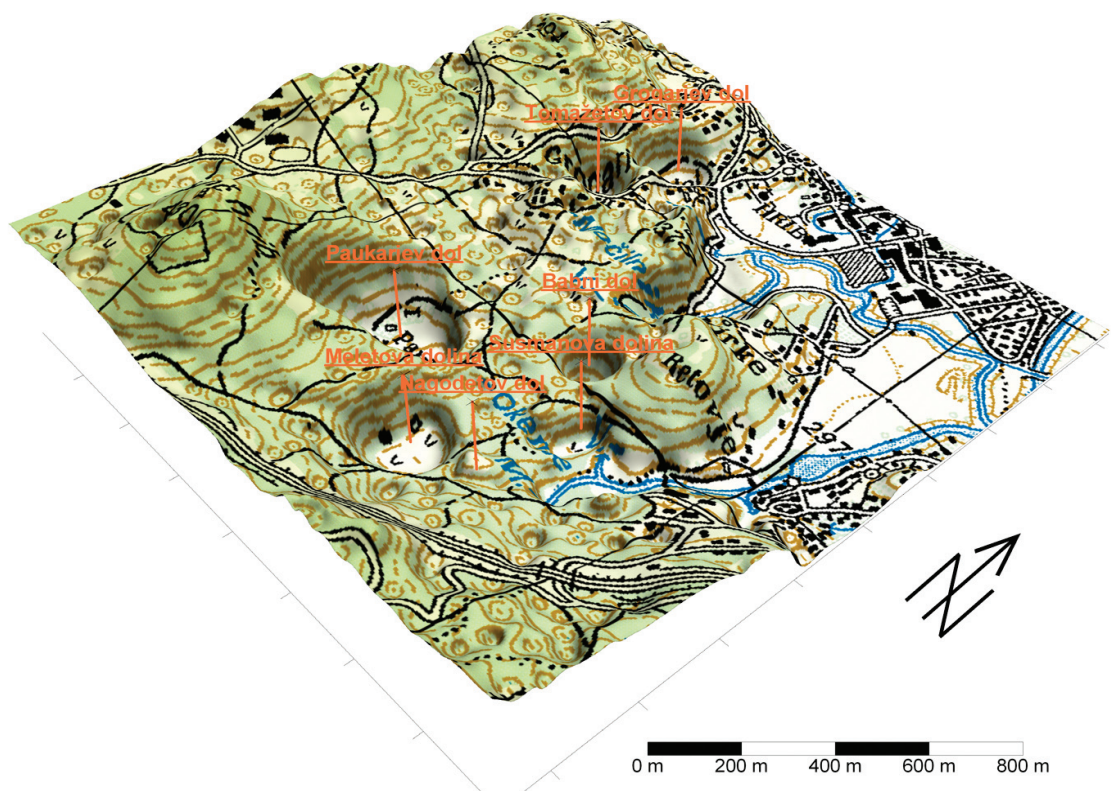

O udornicah v zaledju izvirov Ljubljanice je pisal Habič (1963), ki je ugotovil, da imajo dna urejena v enem izrazitem višinskem nivoju. Sklepal je, da so bile jame oblikovane v izrazitem nivoju, zato ker je odnašanje podora trajalo do trenutka, ko so udornice zazijale na površje. Raziskave jamskega sistema in fragmenti brezstropih jam v območju kažejo, da je jamski sveženj v območju bil in še vedno je freatičen, torej ni urejen v nivoju (Ilič, 2002; Stepišnik, 2003; Kataster jam JZS, 2005). Hkrati ne poznamo mehanizma, ki bi povzročil umik vode iz jame v trenutku, ko bi jamska dvorana nad njo zazijala na površje (Stepišnik, 2003).

Razporeditev uravnanih dnov udornic na izrazitem višinskem nivoju nastane zato, ker dna udornic segajo v epifreatično območje nihanja piezometričnega nivoja, ki je zajezen s talno vodo Ljubljanskega barja, ki leži na nadmorski višini 297 metrov. Dna so ob visokem vodostaju poplavljena, iz stoječe vode pa se odlaga lebdeči tovor. Tako nastanejo ilovnata uravnana dna do višine poplavnih vod, ki na manjšem območju sežejo približno enako visoko (Stepišnik, 2003). 
$\mathrm{Z}$ meritvami električne upornosti tal, ki sem jih opravil z geoelektričnim radarjem SuperSting R1/IP, sem podrobneje preučil lastnosti ilovnatih uravnav v Grogarjevem dolu, Paukarjevi dolini, Meletovi dolini, Susmanovem dolu in Nagodetovem dolu. Te udornice so edinstven primer uravnavanja dnov na isti nadmorski višini $v$ neposrednem zaledju kraških izvirov, ki uravnavajo višino piezometra. Metoda omogoča meritve vzdolžnih profilov električne upornosti tal. Globina zajemanja podatkov je odvisna od oblikovanosti in dolžine profila in seže največ do 45 metrov. Pri meritvah sem uporabil matodo dipol dipol, ki se je izkazala za najbolj uporabno podlago, kjer prevladuje kombinacija med relativno slabo električno uporno ilovico, ki vsebuje velik delež vode, ter apnenci, ki so relativno slabo prevodni.

\section{GROGARJEV DOL}

V skupini vrhniških udornic je Grogarjev dol med domačini najbolj znan. Od južnejšega Tomažetovega dola ga loči 35 metrov visok greben. Udornica je razpotegnjena v smeri severjug. Daljši premer udornice je 175 metrov, krajši premer 145 metrov. Povprečna globina udornice je 35 metrov, prostornina je $0,35 \mathrm{Mm}^{3}$ (slika 2).

\section{Slika 2: Grogarjev dol}

Figure 2: Grogarjev dol

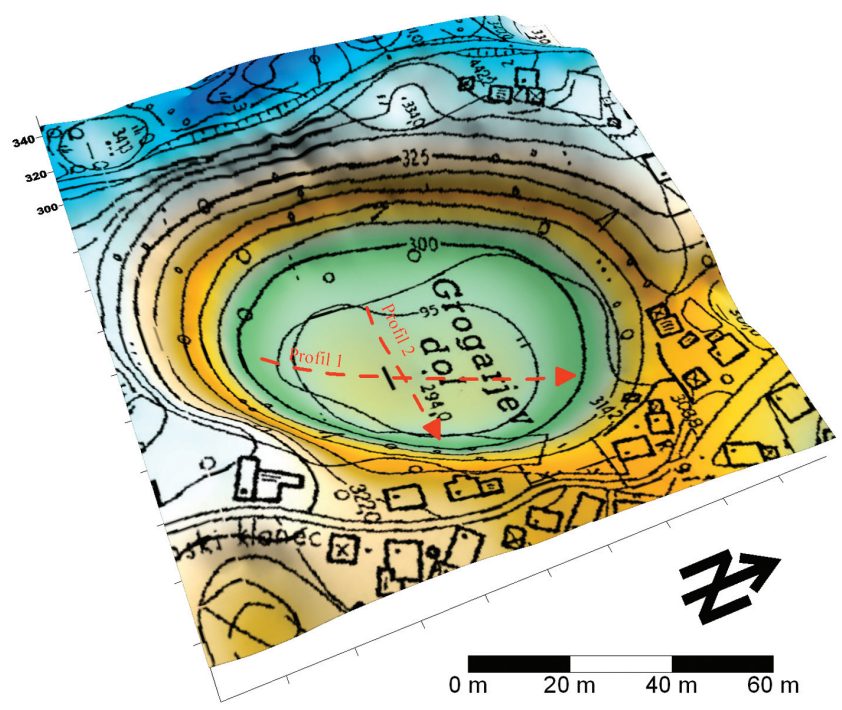

Ob visoki podtalnici dno zalije voda in v njem nastane jezero. $V$ času poplav lahko voda $\mathrm{v}$ udornici narase za 6,5 metra nad najnižjim delom dna in tako seže do kote 300,5 metra. Zelo kalna voda priteka $\mathrm{v}$ udornico iz izvira $\mathrm{v}$ zahodnem delu dna. Navadno ponira v najnižjem 
delu dna, ki je v bližini vzhodnega pobočja. Poplavne vode, ki se pojavljajo v udornici, s seboj $\mathrm{v}$ velikih količinah prinašajo droben suspendiran material, kateri se $\mathrm{v}$ udornici odlaga in ustvarja uravnavo. Enak proces je verjetno deloval tudi v vseh ostalih udornicah v zaledju izvirov Ljubljanice, saj imajo vse podobna zapolnjena in uravnana dna na nadmorskih višinah, ki so blizu ali pa celo v območju nihanja podtalnice (Stepišnik, 2003).

Pobočja so v severnem delu večinoma spremenjena z antropogenimi nasipi, nekaj manjših sten je le v delih vzhodnega in zahodnega pobočja. Dno prekriva uravnan ilovnat sediment na nadmorski višini 294 metrov, kar je najnižja kota uravnave dna v tej skupini udornic.

Z uporabo geoelektričnega radarja (slika 3 in slika 4) sem ugotovil, da je globina ilovnatega polnila v udornici okoli 22 metrov, torej da živoskalno dno udornice leži okoli 20 metrov pod nivojem Ljubljanskega barja. Pod relativno enotno živoskalno dno sega le jašek, ki je manj električno uporen, in je bodisi prelomna cona, ob kateri se je udornica oblikovala, bodisi jašek, kjer je material ob oblikovanju udornice odtekal v aktivne freatične jamske rove.

Slika 3: Geoelektrični profil 1 preko Grogarjevega dola

Figure 3: Geoelectrical profile 1 trough Grogarjev dol

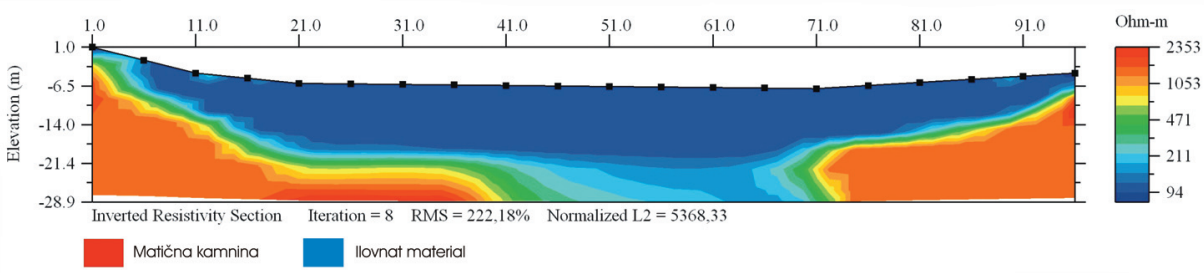

Slika 4: Geoelektrični profil 2 preko Grogarjevega dola

Figure 4: Geoelectrical profile 2 trough Grogarjev dol

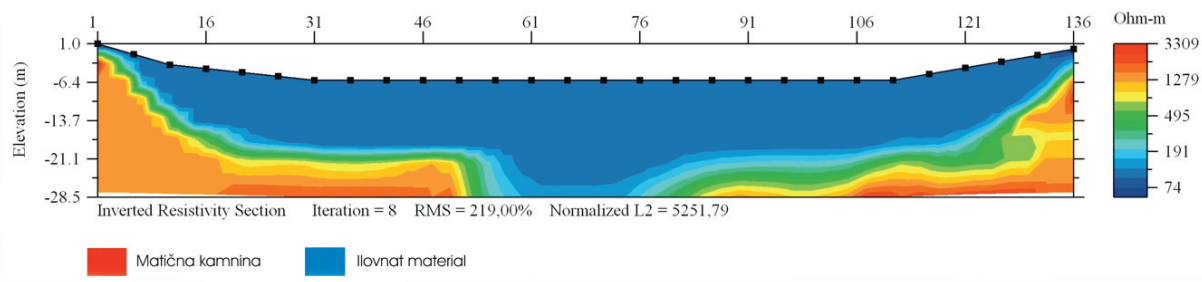

\section{PAUKARJEVA DOLINA}

Paukarjeva dolina leži 300 metrov jugozahodno od izvira Veliki Močilnik, v severovzhodnem pobočju Konč hriba in 200 metrov južno od Grogarjevega dola. Ima največjo prostornino v tej skupini udornic. Ime je dobila po priimku gospodarja kmetije, ki 
živi v njenem dnu. Daljši premer udornice je 275, krajši premer pa 225 metrov. Povprečna globina udornice je 55 metrov, prostornina pa 1,33 $\mathrm{Mm}^{3}$ (slika 5).

\section{Slika 5: Paukarjeva dolina}

\section{Figure 5: Paukarjeva dolina}

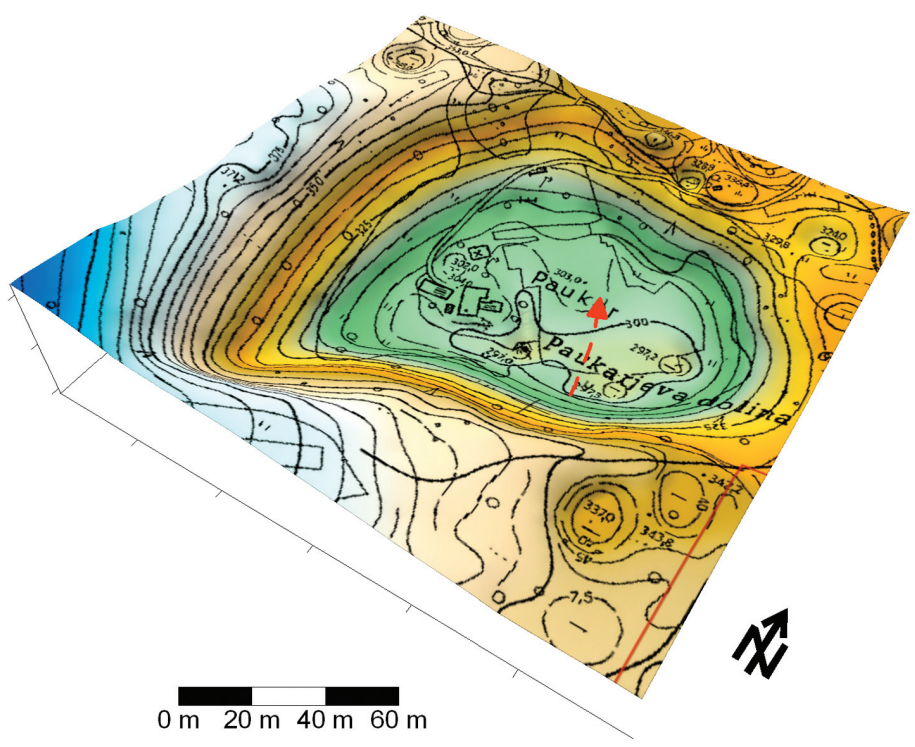

Prevladujejo uravnotežena pobočja, ki jih mestoma prekinjajo manjša in neizrazita aktivna pobočja. Na pobočjih ni večjih akumulacij prepereline. Prehod med pobočji in ilovnatim dnom je oster. Sediment v dnu udornice je vegav in rahlo visi proti najnižji točki, ki je na 297 metrov na južnem delu dna, kjer je tudi kal. K najnižji točki dna od severozahoda sega plitva struga, vrezana $v$ ilovnat sediment. Ob visokih nivojih piezometra po strugi teče voda, ki izvira v severozahodnem delu dna v bližini kozolca.

$\mathrm{V}$ pobočjih udornice ni večjih količin ilovnatega sedimenta, ki bi ga lahko spiralo $\mathrm{V}$ udornico. Sediment v dnu udornice najdemo do nadmorske višine okoli 305 metrov, kar je primerljivo z višino sedimenta v višjih delih dna Meletove doline, ki leži vzhodno od te udornice. Nepravilna oblikovanost površine dna je posledica spiranja sedimenta iz udornice $\mathrm{v}$ podzemlje. V tej udornici spiranje ilovice $\mathrm{z}$ dna povzroča tudi voda epifreatične cone, ki se ob visokih vodostajih površinsko pretaka po strugi v dnu udornice.

Geoelektrični profil Paukarjeve doline (slika 6) kaže, da je debelina ilovnatega sedimenta $\mathrm{v}$ dnu udornice večja od 28 metrov. Živoskalno dno udornice torej sega vsaj nekaj deset metrov pod nivo Ljubljanskega barja, torej je udornica nastala $\mathrm{z}$ odnašanjem materiala $\mathrm{v}$ jamskih rovih freatične cone. 
Slika 6: Geoelektrični profil preko Paukarjeve doline

Figure 6: Geoelectrical profile trough Paukarjeva dolina

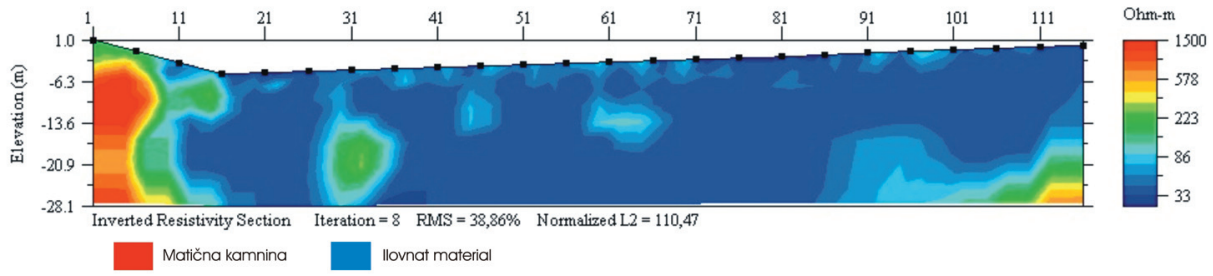

\section{MELETOVA DOLINA}

Meletova dolina leži vzhodno od Paukarjeve doline. Med obema udornicama je okoli 70 metrov širok in 30 metrov visok greben. Daljši premer udornice je 200 metrov, medtem ko je krajši premer 135 metrov. Povprečna globina udornice je 33 metrov, prostornina udornice je $0,35 \mathrm{Mm}^{3}$ (slika 7).

Slika 7: Meletova dolina in Nagodetov dol

Figure 7: Meletova dolina and Nagodetov dol

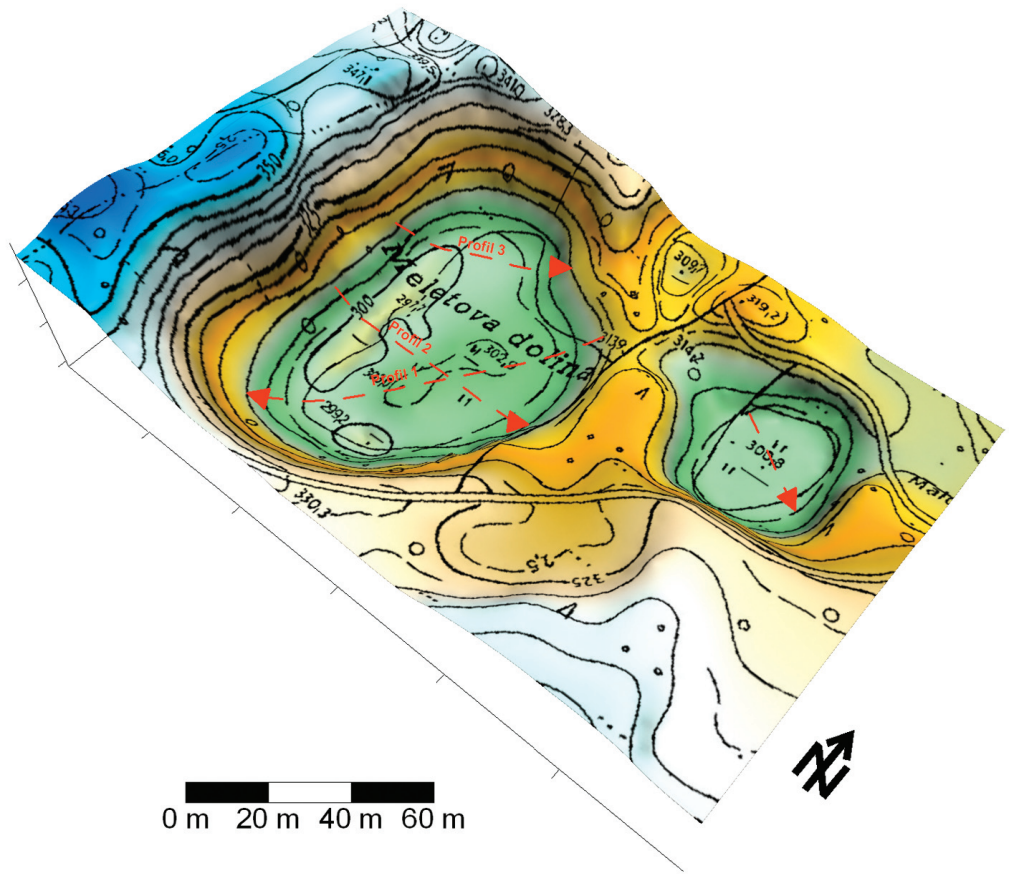


Vzhodna in severna pobočja Meletove doline so večinoma uravnotežena. Ostala pobočja so stenovita, pod njimi pa so razvita manjša melišča, ki segajo do uravnanega ilovnatega dna. Sediment v dnu je rahlo vegav in blago upada od severovzhodne strani, kjer ima nadmorsko višino 302 metra, proti južni in zahodni strani, kjer je najnižji del dna na nadmorski višini 297 metrov. V najnižjem delu udornice so pod melišči do dva metra goboke globeli. V nekaterih je prisoten recenten proces spodjedanja. $Z$ višjih delov dna vodijo do kotanj manjši jarki, ki najbolj spominjajo na struge. Manjše kotanje v ilovnatem sedimentu nastajajo tudi v ostalih delih dna, a jih ljudje sproti mašijo zaradi košnje.

Nepravilna oblikovanost ilovnatega dna je rezultat površinskega in podzemskega spiranja ilovice. Padavinska voda se ob večjih padavinah površinsko pretaka po neprepustnem površju dna in odnaša ilovnat material. V območjih kjer se pretaka v lokalno koncentriranih tokovih, nastanejo manjše struge. Vodijo do lijakastih globeli, kjer voda ilovico spira $\mathrm{v}$ podzemlje. Spomladi leta 2005 je v zahodnem delu dna udornice nastal grez v ilovnatem materialu, ki priča o recentnem spodjedanju. Podzemsko spiranje lahko povzroča koncentrirana voda $\mathrm{v}$ preperelini ali pa voda freatične cone, ki v območju udornic predvidoma teče proti izvirom v Retovju in Močilniku.

Meritve električne upornosti tal kažejo (slika 8, slika 9 in slika 10), da je debelina ilovnatega materiala $\mathrm{v}$ dnu udornice vsaj 25 metrov. V severnem delu dna je globina ilovnate zapolnitve 15 metrov, pod njo leži električno bolj uporna matična podlaga. Električno bolj uporna območja se nahajajo tudi pod melišči v zahodnem in južnem delu udornice.

Slika 8: Geoelektrični profil 1 preko Meletove doline

Figure 8: Geoelectrical profile 1 trough Meletova dolina

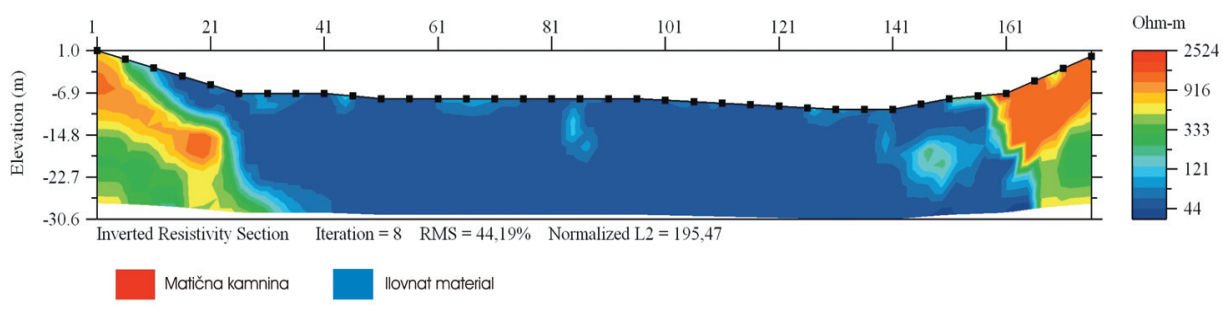

Slika 9: Geoelektrični profil 2 preko Meletove doline

Figure 9: Geoelectrical profile 2 trough Meletova dolina

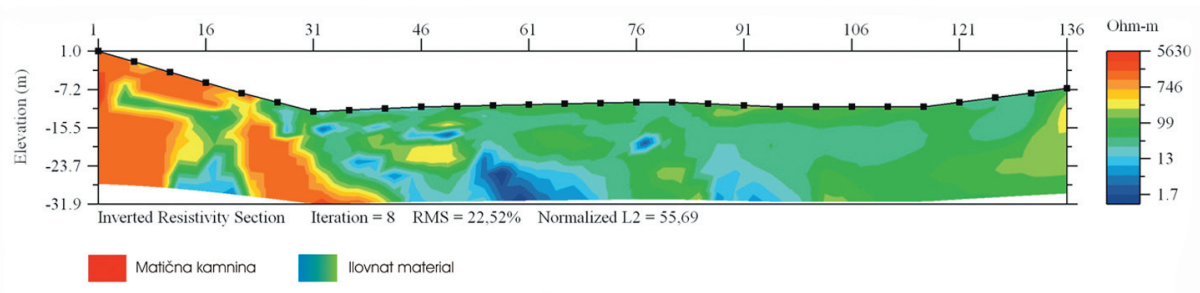


Slika 10: Geoelektrični profil 3 preko Meletove doline

Figure 10: Geoelectrical profile 3 trough Meletova dolina

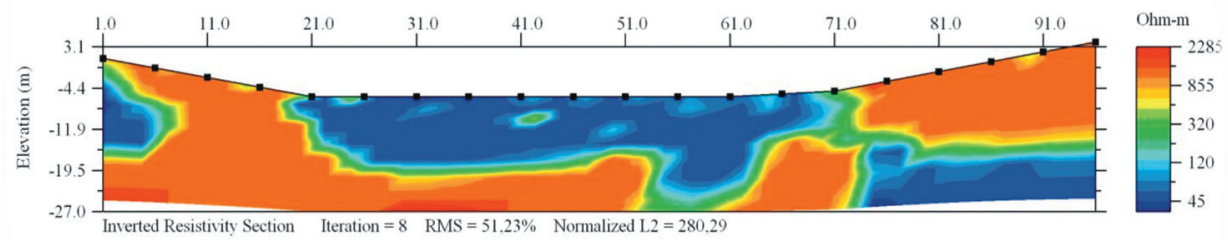

Matična kamnina Ilovica

\section{NAGODETOV DOL}

Nagodetov dol leži okoli 70 metrov jugozahodno od izvira Veliko okence v Retovju. Do njega vodi suh jarek, ki se prične v zatrepni dolini 30 metrov od izvira Veliko okence. Daljši premer udornice meri 85 metrov, krajši pa 65 metrov. Povprečna globina udornice je 18 metrov, prostornina pa $0,03 \mathrm{Mm}^{3}$ (slika 7).

Nagodetov dol je najmanjša in najplitvejša udornica v okolici. Vzhodna in severna pobočja so strmejša in mestoma stenasta, ostala pobočja so večinoma uravnotežena. Dno je zapolnjeno in uravnano z ilovico na nadmorski višini 300,8 metrov. Nekaj deset metrov vzhodno od udornice potekajo glavni aktivni freatični kanali, ki prevajajo vodo do izvira Veliko okence (Ilič, 2002).

Meritve profilov električne upornosti tal $v$ udornici so pokazale, da je debelina ilovnatega materiala v dnu udornice vsaj 15 metrov (slika 11). V vzhodnem delu dna je pri vrhu ilovnate uravnave električno bolj uporno območje. Gradi ga ilovica s pobočnim gruščem, ki ima izvor v strmem in stenastem vzhodnem pobočju. Prav tako je v globini 10 metrov v vzhodnem delu dna vidno električno bolj uporno območje, ki je po vsej verjetnosti apnenčast grušč enakega izvora. To pomeni, da je zapolnjevanje udornice $\mathrm{z}$ ilovnatim materialom potekalo sočasno $\mathrm{s}$ fazami akumulacije pobočnega materiala.

Slika 11: Geoelektrični profil preko Nagodetovega dola

Figure 11: Geoelectrical profile trough Nagodetov dol

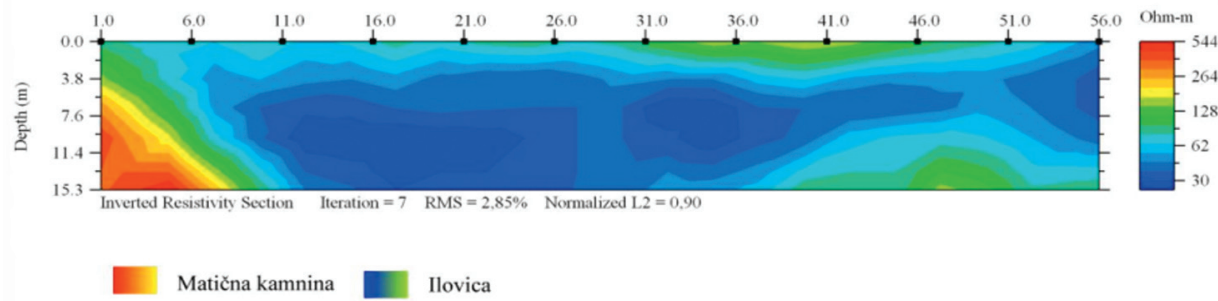




\section{SUSMANOVA DOLINA}

Susmanovo dolino od zatrepa izvira Malo okence v Retovju loči le ozek, 8 metrov visok greben. Udornica je v tlorisu razpotegnjena v smeri sever-jug. Daljši premer udornice je 130 metrov, krajši premer pa 70 metrov. Povprečna globina udornice je 18 metrov, prostornina pa $0,68 \mathrm{Mm}^{3}$ (slika 12).

\section{Slika 12: Susmanova dolina}

Figure 12: Susmanova dolina

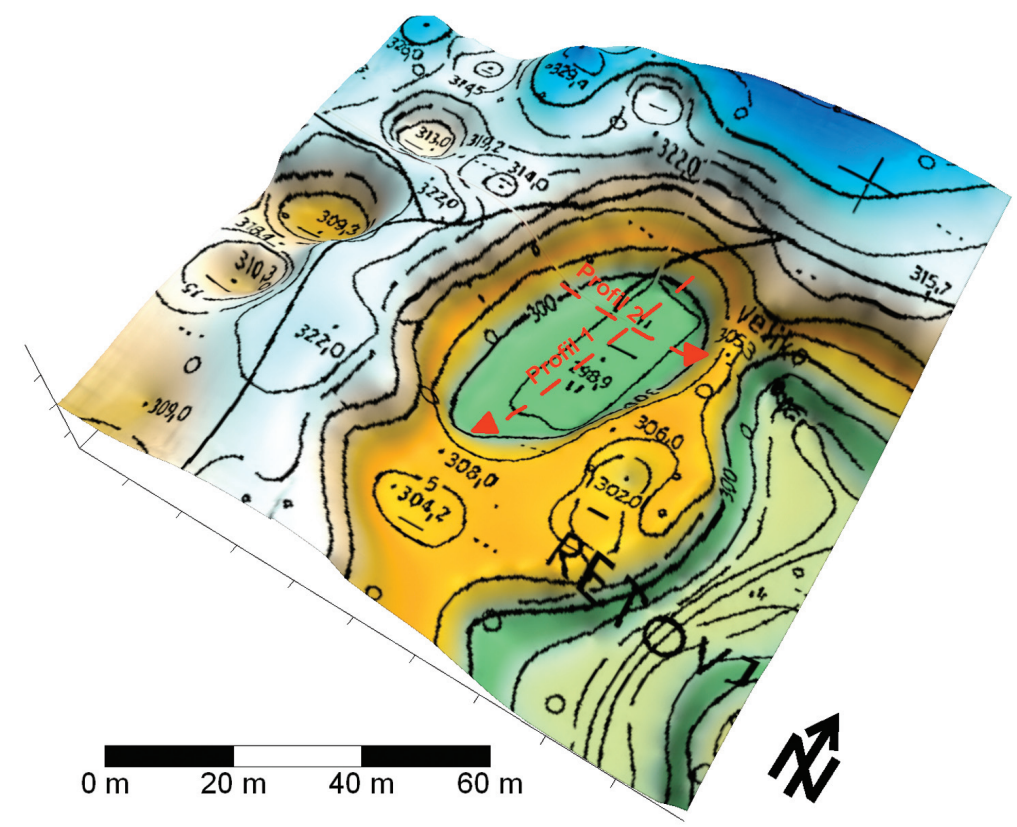

Uravnotežena pobočja udornice so prekinjena le na nekaj območjih v južnem delu, kjer prevladujejo pobočni procesi. Prehod med pobočji udornice in ilovnatim uravnanim dnom na nadmorski višini 299 metrov je oster. Ilovnato dno je elipsaste oblike, razpotegnjeno v smeri sever-jug in povsem ravno.

Gladina izvira Malo okence je na nadmorski višini 295 metrov, torej je le 4 metre nižje od ilovnatega dna udornice. Jama v zaledju izvira Malo okence je popolnoma freatična in poteka severno od Susmanove doline proti Velikemu Močilniku (Ilič, 2002).

Globina ilovnatega sedimenta v osrednjem delu dna udornice je 25 metrov, v severnem delu dna pa seže globlje od 28 metrov (slika 13 in slika 14). Dno udornice je 20 metrov pod Ljubljanskim barjem. 
Slika 13: Geoelektrični profil 1 preko Susmanove doline

Figure 13: Geoelectrical profile 1 trough Susmanova dolina

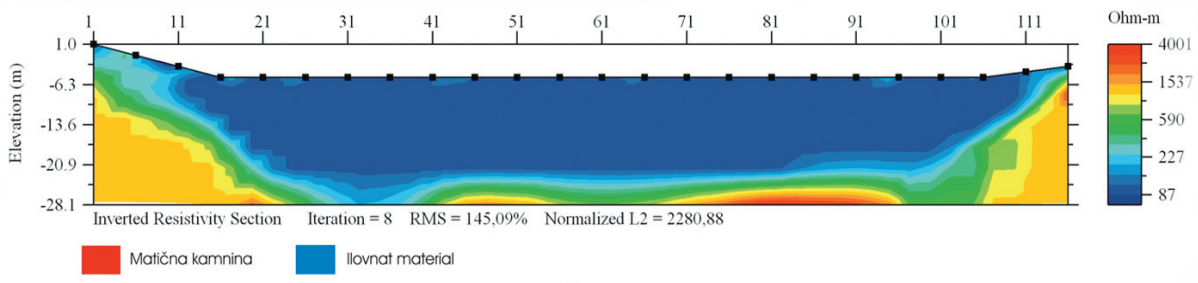

Slika 14: Geoelektrični profil 2 preko Susmanove doline

Figure 14: Geoelectrical profile 2 trough Susmanova dolina

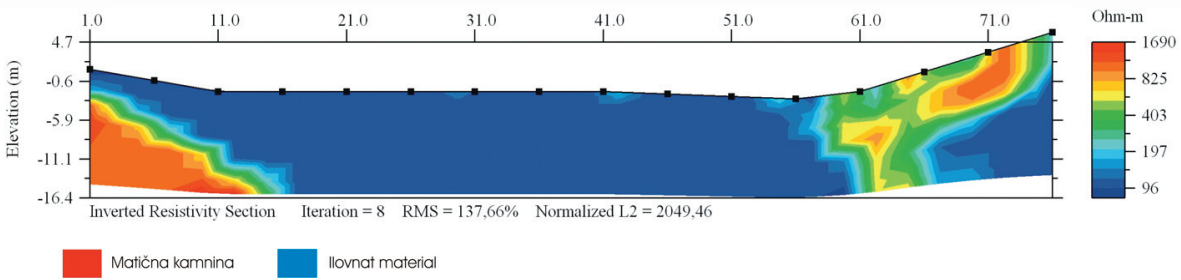

\section{SKLEPI}

Podrobnejši pregled procesov oblikovanja in preoblikovanja udornic, oblikovanosti dnov udornic ter podrobnejšo analizo ilovnatega materiala $\mathrm{v}$ dneh udornic je dal naslednje zaključke:

- $\quad \mathrm{Na}$ pobočjih udornic so aktivni različni procesi. Prevladujejo procesi mehanskega premeščanja materiala vzporedno s pobočjem navzdol, redkejša so uravnotežena pobočja, kjer prevladuje odtok materiala v raztopini.

- $\quad$ Udornice so nastale nad aktivnimi rovi freatične cone, ki leži pod današnjim nivojem Ljubljanskega barja. Znani aktivni jamski rovi danes več ne potekajo pod udornicami ampak v njihovi bližini.

- Dna udornic so zapolnjena in relativno uravnana z ilovnatim materialom. Material se je odložil iz poplavne vode, ki je ob višjih nivojih piezometra zapolnjevala oziroma ojezerila dna udornic. Proces ojezerjevanja in odlaganja poplavne ilovice je redno prisoten v Grogarjevem dolu, kar je edini znan recentni tovrstni proces na slovenskem krasu.

- Nadmorske višine dnov ilovnatih uravnav v dneh udornic so na nadmorskih višinah med 294 in 304 metri, zato ker je nivo Ljubljanskega barja pri Vrhniki približno na nadmorski višini 297 metrov. Višina talne vode na Ljubljanskem barju kontrolira višino piezometra v kraškem zaledju. 
- Globina ilovnatih zapolnitev v udornicah je več kot 30 metrov. Vse zapolnitve segajo pod nivo Ljubljanskega barja. Udornice, ki so nastale nad freatičnim jamskim sistemom, so se postopoma zapolnile in uravnale z ilovnatim sedimentom.

\section{Viri in literatura}

Cramer, H., 1941. Die Systematik der Karstdolinen. Neues Jahrbuch für Mineralogie, Geologie und Paläontologie, 85, 1, str. 293-382.

Ford, D.C., Williams, P., 1989. Karst Geomorphology and Hidrology. Wellington, Uniwin Hyman, 601 str.

Gams, I., 1973. Slovenska kraška terminologija. Ljubljana, Slovenska matica, 76 str.

Gams, I., 2004. Kras v Sloveniji v prostoru in času. 2. izdaja, Založba ZRC, 515 str.

Gospodarič, R., Habič, P., 1976. Underground water tracing, investigations in Slovenia 19721975. IZRC SAZU, 309 str.

Habič, P., 1963. Udorne vrtače - koliševke in podzemski tokovi. Treći Jugoslovenski speleološki kongres, Speleološki savez Jugoslavije, Sarajevo, str. 1-272.

Ilič, U., 2002. Nove raziskave v Velikem in Malem Okencu: Naše jame, 44, str. 124-131.

Kataster jam JZS, 2005. Jamarska zveza Slovenije.

Pleničar, M., 1963. Tolmač osnovne geološke karte za list Postojna. Geološki zavod Ljubljana, 53 str.

Scheidegger, A. E., 1974. Theoretical Geomorphology. Springer - Verlag, Berlin, 435 str.

Šivic, Dular, A., 2005. Izvor imen koliševka in kukava. (osebni vir, december 2005)

Stepišnik U., 2001. Udornice na Postojnskem krasu. Diplomsko delo, Filozofska fakulteta Univerze v Ljubljani, Oddelek za geografijo, 99 str.

Stepišnik, U., 2003. Morfogenetske značilnosti vrhniških udornic. Naše jame 45, str. 34 - 47.

Stepišnik, U., 2006. Udornice na slovenskem krasu. Doktorska disertacija, Filozofska fakulteta, Oddelek za geografijo, 192 str.

Šušteršič, F., 1984. Preprost model preoblikovanja udornic. Acta carsologica, 12, 1, str. 107138.

\section{LOAMY FILLS IN COLLAPSE DOLINES NEAR LJUBLJANICA SPRINGS}

\section{Summary}

On karst surface many different closed karst depressions are known. Collapse dolines are by definition karst depressions formed as a result of cave chambers collapses. This process gave the name to collapse dolines. In Slovenian karstological terminology the term collapse doline is usually used for a closed karst depression of exceptional dimensions or steep rocky walls. Limited dimensions of cave chambers results in the formation of small collapse dolines. On the other hand the formation and location of collapse dolines of greater dimensions are closely related to specific underground hydrology. 
The article is focused on the study of geomorphologic features and processes in collapse dolines. Due to the processes in collapse dolines, different morphology developed. The development of slopes in collapse dolines is the result of the balance between the dynamics of both, mechanical slope processes and chemical corrosion of bedrock. The morphology of floors is also result of dynamics of undermining from below, weathering and slope processes. Flat loamy sediment floors in some collapse dolines are the result of suspended material sedimentation from floodwaters that inundated lower parts of collapse dolines.

In hinterland of the Ljubljanica spring near Vrhnika is a group of seven collapse dolines of greater dimensions. Most of the slopes of collapse dolines have active mechanical slope processes, some also have steep stone walls and screes. The floors are filled and flattened with loamy sediment fills. The elevation of the floors is between 294 and 304 meters.

Similar floor elevations inside the collapse dolines suggest that the process that led to sedimentation of the fine loamy sediment from stagnant water was active across a wide area, not just locally inside isolated collapse doline. The deposition of the loamy sediment fills inside collapse dolines resulted from higher water table level inside karst which was controlled by elevation of Ljubljana moor on 297 meters. The thickness of loamy sediment fills might reach more than 40 meters. 